Discussion Paper No. 1038

\title{
MONEY-FINANCED FISCAL STIMULUS: THE EFFECTS OF IMPLEMENTATION LAG
}

\author{
Takayuki Tsuruga \\ Shota Wake
}

August 2018

The Institute of Social and Economic Research

Osaka University

6-1 Mihogaoka, Ibaraki, Osaka 567-0047, Japan 


\title{
Money-Financed Fiscal Stimulus: The Effects of Implementation Lag*
}

\author{
Takayuki Tsuruga ${ }^{\dagger}$ and Shota Wake
}

First draft: March 2016

This version: August 2018

\begin{abstract}
Previous studies argue that, based on the New Keynesian framework, a fiscal stimulus financed by money creation has a strong positive effect on output under a reasonable degree of nominal price rigidities. This paper investigates the effects of implementation lag in the moneyfinanced fiscal stimulus on output. We show that if a money-financed government purchase has a time lag between the decision and the implementation: (1) it may cause a recession rather than a boom when the economy is in normal times; (2) it may deepen a recession when the economy is caught in a liquidity trap; (3) the longer is the implementation lag, the deeper is the recession; and (4) the depth of the recession depends on the interest semi-elasticity of money demand. Our results imply that to strengthen the efficacy of the money-financed fiscal stimulus, policymakers should shorten the implementation lag based on detailed knowledge of the money demand function.
\end{abstract}

JEL Classification: E32; E52; E62

Keywords: Anticipation effect, Fiscal multiplier, Government spending, Seigniorage

\footnotetext{
${ }^{*}$ We would like to thank Bill Dupor, Ryo Horii, Kenneth Kuttner, Taisuke Nakata, Makoto Saito, and Masahiko Shibamoto and seminar and conference participants at Kobe University, Shiga University, the University of Tokyo, and the Asian Meeting of the Econometric Society for helpful discussions and comments. This paper was previously circulated as "Money-Financed Fiscal Stimulus: The Effects of an Anticipated Shock." Takayuki Tsuruga acknowledges the financial support from Grants-in-Aid for Scientific Research (15H05729 and 15H05728), the Murata Science Foundation, and the Zengin Foundation for Studies on Economics and Finance. The views expressed in this paper are those of the authors and do not necessarily reflect the official views of the Government of Japan.

${ }^{\dagger}$ Osaka University; Cabinet Office, the Government of Japan; Centre for Applied Macroeconomic Analysis

${ }^{\ddagger}$ Cabinet Secretariat, the Government of Japan
} 


\section{Introduction}

Government spending to stimulate the economy is typically financed through government debt and eventually taxes. The global financial crisis in the last decade led to high levels of the government debt-to-GDP ratio in many countries and these countries' policy interest rates hit the zero lower bound (ZLB). Against this backdrop, some argue that a fiscal stimulus financed by money creation can be considered a policy option to boost aggregate demand (Galí 2017, English, Erceg and López-Salido 2017, among others). ${ }^{1}$ This policy option relies neither on lowering the nominal interest rate nor on further issuance of government debt, because the fiscal stimulus is financed by seigniorage. Using the standard New Keynesian model with a reasonable degree of nominal rigidities, Galí (2017) shows that an unexpected shock to money-financed government purchases or tax cuts can have a large positive impact on output along with a crowding-in effect on consumption. English, Erceg and López-Salido (2017) also argue that a money-financed fiscal stimulus is a powerful tool for boosting aggregate demand if such fiscal policy is credible. Overall, these studies find that the money-financed fiscal stimulus can increase output and inflation as well as reduce the debt-to-GDP ratio substantially.

This paper investigates the role of an implementation lag in the effect of money-financed government purchases. The introduction of an implementation lag of fiscal policy into the standard New Keynesian model is a straightforward extension of the model. However, it captures an important aspect of fiscal policy and thus has been widely discussed in the literature. Ramey (2011) provides empirical evidence that government purchases tend to involve long lags between the decision to spend and the actual increase in spending. Cwik and Wieland (2011) assess the effect of debt-financed fiscal policy with an implementation lag, using a variety of empirical New Keynesian models. Yang (2005), Leeper, Walker and Yang (2010), Leeper, Richter and Walker (2010), Mertens and Ravn (2011), and Fujiwara and Waki (2017), among others, analyze a distortionary tax and find that model responses to an announced tax change differ substantially from those to an unanticipated tax change as well as their policy implications.

We present four findings, in all of which the implementation lag plays an important role for the efficacy of the money-financed fiscal stimulus. The first finding is that, if the money-financed fiscal stimulus involves an implementation lag, the fiscal stimulus may cause a recession rather than a boom. This is in sharp contrast to a money-financed fiscal stimulus without an implementation

\footnotetext{
${ }^{1}$ For more practical discussions on the efficacy of money-financed fiscal stimulus, see also Turner (2015).
} 
lag, in which the fiscal stimulus boosts aggregate demand strongly as discussed in the literature.

The mechanism behind our first finding can be understood from an influential study by Ball (1994), who finds that a credible disinflationary announcement in the presence of nominal rigidities causes a boom rather than a recession. In his analysis, if a decline in the money growth rate is anticipated, forward-looking firms reduce prices prior to the actual decline in the money growth rate. Ball (1994) assumes that households' consumption is constrained by their real money balances (i.e., the cash-in-advance (CIA) constraint). In this case, the lower aggregate prices result in higher real money balances and relax the CIA constraint. The resulting higher aggregate demand leads to a boom prior to the decline in the money growth rate.

Ball's (1994) argument is applicable to our context, but in an opposite direction. In our analysis, if the money-financed fiscal stimulus is anticipated in advance because of an implementation lag, forward-looking firms increase prices prior to the actual increase in money supply that finances the fiscal stimulus. The higher aggregate prices result in lower real money balances and tighten the CIA constraint. The resulting lower aggregate demand leads to a recession prior to the implementation of the money-financed fiscal stimulus.

The second finding of this paper is that such a negative effect on output remains even when the economy is caught in a liquidity trap. If the money-financed fiscal stimulus is implemented without a lag, the economy experiences a faster recovery from a recession caused by the liquidity trap than the case of no policy change. However, an implementation lag in the money-financed fiscal stimulus may result in a slower recovery from the recession than the case of no policy change.

The mechanism behind our second finding is slightly different from that behind the first finding. Because the nominal interest rate is zero in the liquidity trap, there is no opportunity cost of holding money. In this case, it is not necessarily optimal for the household to reduce money holding to the level required for its consumption and thus the CIA constraint does not bind. Once the CIA constraint does not bind, current consumption is influenced by the dynamic path of the real interest rate through the Euler equation.

When the money-financed fiscal stimulus is announced, households and firms know that the future government spending will raise the real interest rate at the time of implementation. A high real interest rate in the future crowds out current consumption through the Euler equation. As long as the real interest rate increases sufficiently, current consumption is crowded out by the money-financed fiscal stimulus with an implementation lag. By contrast, the money-financed fiscal stimulus without an implementation lag immediately generates higher inflation because of 
the actual increases in the money supply and government purchases. Higher inflation under the liquidity trap leads to higher aggregate demand so that consumption is higher than in the case of no policy change.

Turning to the third finding, we show that the negative effect becomes stronger as the implementation lag of the money-financed fiscal stimulus lengthens. The intuition is simple, especially in the case of the binding CIA constraint. If the implementation lag lengthens, the firms have more opportunity to increase prices before the implementation. As a result, the aggregate price level increases and the CIA constraint becomes tighter, reducing consumption. Therefore, the recession is deeper, as the implementation lag is longer.

Finally, our analysis also suggests the importance of the interest semi-elasticity of money demand for the efficacy of the money-financed fiscal stimulus with an implementation lag. If money demand is inelastic with respect to the nominal interest rate, the money market equilibrium condition suggests that a reduction in real money balances resulting from higher prices needs to be absorbed by a large increase in the nominal interest rate. Therefore, if the increase in the nominal interest rate transmits to the real interest rate, it weakens aggregate demand. By contrast, if money demand is elastic with respect to the nominal interest rate, the reduced real money balances can be absorbed by a small increase in the nominal interest rate. As a result, even when the money-financed fiscal stimulus is implemented with a lag, the real interest rate can be kept low, supporting aggregate consumption. Therefore, the money-financed fiscal stimulus under a high interest semi-elasticity of money demand may have a strong positive effect on output, even with an implementation lag.

We thus conclude that the efficacy of a money-financed fiscal stimulus depends on the length of the implementation lag and the interest semi-elasticity of money demand. An implication for fiscal policy is that policymakers should consider the interest semi-elasticity of money demand in evaluating the money-financed fiscal stimulus. If policymakers are faced with a low interest semielasticity of money demand, they should shorten the implementation lag of the fiscal stimulus. If the implementation lag is difficult to shorten, the money-financed fiscal stimulus would be a useful policy option only under a high interest semi-elasticity of money demand.

\section{The model}

The model we consider is a stylized New Keynesian model with an occasionally binding ZLB constraint on the nominal interest rate. We also use a CIA constraint in modeling money demand. 
Previous studies such as English, Erceg, and López-Salido (2017) and Galí (2017) examine a moneyfinanced fiscal stimulus that is implemented without a lag and compare the equilibrium dynamics with a debt-financed fiscal stimulus. By contrast, we focus on an implementation lag in a moneyfinanced fiscal stimulus and investigate the impact of the implementation lag on the effect of the fiscal stimulus. Following Galí (2017), we assume a deterministic environment other than Calvo pricing. We also consider a model with an occasionally binding ZLB constraint under a deterministic environment.

\subsection{Households and firms}

A representative household maximizes its lifetime utility given by $\sum_{t=0}^{\infty} \beta^{t} U\left(C_{t}, N_{t}\right)$, where $U\left(C_{t}, N_{t}\right)=\left[C_{t}^{1-\sigma} /(1-\sigma)-N_{t}^{1+\varphi} /(1+\varphi)\right] Z_{t}$. Here, $C_{t}, N_{t}$, and $Z_{t}$ represent consumption, labor supply, and an exogenous preference shifter, respectively. The parameters $\sigma>0, \varphi>0$, and $0<\beta<1$ denote the degree of relative risk aversion, the inverse of the Frisch elasticity of labor supply, and the discount factor, respectively. Throughout the model, the unit of time $t$ is one quarter. The household faces a budget constraint and a CIA constraint as follows:

$$
\begin{aligned}
M_{t}+B_{t} & =\left(1+I_{t-1}\right) B_{t-1}+\left(M_{t-1}-P_{t-1} C_{t-1}\right)+W_{t} N_{t}+P_{t} D_{t}-P_{t} T_{t}, \\
M_{t} & \geq P_{t} C_{t},
\end{aligned}
$$

where $M_{t}$ is nominal money holdings, $B_{t}$ denotes households' nominal holdings of one-period government bonds that pay the nominal interest rate $I_{t}, P_{t}$ represents the aggregate price index, and $W_{t}$ is nominal wages. Furthermore, $D_{t}$ denotes firms' real profits and $T_{t}$ is lump-sum taxes in real terms. The left-hand side of (1) is the nominal value of total wealth that the household brings into period $t$. The right-hand side indicates that the household receives the nominal income $W_{t} N_{t}+P_{t} D_{t}$ and pays taxes $P_{t} T_{t}$. It also carries the nominal bond and cash holdings remaining after consumption into period $t$. As usual, a no Ponzi game condition holds. Equation (2) is the CIA constraint.

The first-order conditions are standard:

$$
\begin{aligned}
\frac{U_{C, t}}{P_{t}} & =\beta\left(1+I_{t}\right) \frac{U_{C, t+1}}{P_{t+1}}, \\
-\frac{U_{N, t}}{U_{C, t}} & =\frac{W_{t}}{P_{t}} \\
M_{t}-P_{t} C_{t} & \geq 0
\end{aligned}
$$


where $U_{C, t}=C_{t}^{-\sigma} Z_{t}$ and $U_{N, t}=-N_{t}^{\varphi} Z_{t}$. When $I_{t}>0$, (5) holds with equality. This is because holding money beyond the nominal transaction $P_{t} C_{t}$ is not optimal under the strictly positive opportunity cost of money holding. When $I_{t}=0$, however, $M_{t}$ is a perfect substitute for $B_{t}$ in transferring the wealth into the next period and the CIA constraint is not necessarily binding. That is, the CIA constraint may not be binding if the ZLB on the nominal interest rate is binding (and vice versa).

The representative firm produces the final good in a perfectly competitive market. It combines a continuum of intermediate goods, using the technology $Y_{t}=\left(\int_{0}^{1} Y_{t}(j)^{(\epsilon-1) / \epsilon} d j\right)^{\epsilon /(\epsilon-1)}$, where $Y_{t}(j)$ denotes output produced by the intermediate good producers $j \in[0,1]$ and $\epsilon(>1)$ is the elasticity of substitution among differentiated intermediate goods. The aggregate price index $P_{t}$ is associated with intermediate good prices $P_{t}(j)$ by $P_{t}=\left(\int_{0}^{1} P_{t}(j)^{1-\epsilon} d j\right)^{1 /(1-\epsilon)}$. The production function for intermediate good producers is $Y_{t}(j)=N_{t}(j)^{1-\alpha}$, where $\alpha \in(0,1]$. Each intermediate firm is allowed to reset its price with probability $1-\theta$. Let $P_{t}^{*}$ be the optimal nominal price set by an intermediate good producer. The optimal nominal price solves the maximization problem:

$$
\max _{P_{t}^{*}} \sum_{k=0}^{\infty} \theta^{k} Q_{t, t+k}\left(1 / P_{t+k}\right)\left(P_{t}^{*} Y_{t+k \mid t}-W_{t+k} Y_{t+k \mid t}^{\frac{1}{1-\alpha}}\right),
$$

subject to the demand function $Y_{t+k \mid t}=\left(P_{t}^{*} / P_{t+k}\right)^{-\epsilon} Y_{t+k}$, where $Y_{t+k \mid t}$ denotes an intermediate good's output in period $t+k$ for the producer that last reset its price in period $t$ and $Q_{t, t+k} \equiv$ $\beta U_{C, t+k} / U_{C, t}$ is the discount factor of the firm. The first-order condition for $P_{t}^{*}$ is

$$
\sum_{k=0}^{\infty} \theta^{k} Q_{t, t+k}\left(1 / P_{t+k}\right) Y_{t+k \mid t}\left(P_{t}^{*}-\frac{\epsilon}{\epsilon-1} W_{t+k \mid t} Y_{t+k \mid t}^{\frac{\alpha}{1-\alpha}}\right)=0
$$

Along with the price index, log-linearizing this equation around the zero steady-state inflation rate leads to the standard New Keynesian Phillips curve.

\subsection{Government}

Our experiment examines the impact of the money-financed fiscal stimulus with an implementation lag of $h$ periods. Following Galí (2017), let $g_{t}$ be government purchases, which exceed its steady-state level, expressed as a fraction of the steady-state output (i.e., $g_{t} \equiv\left(G_{t}-G\right) / Y$ where $G_{t}$ is government purchases and $G$ and $Y$ are the steady-state value of government purchases and 
output, respectively). At $t=0$, the government announces the following fiscal stimulus:

$$
g_{t}=\left\{\begin{array}{cc}
0 & \text { for } t<h \\
\delta^{t-h} & \text { for } t \geq h
\end{array}\right.
$$

where $h \geq 0$. Here $\delta \in[0,1)$ measures the persistence of an exogenous increase in $g_{t}$ because $g_{t+1}=$ $\delta g_{t}$ for $t \geq h$. For any $h \geq 0$, the magnitude of the initial increase in the government purchases is normalized to one percent of the steady-state output, because $g_{t}$ is defined as $g_{t}=\left(G_{t}-G\right) / Y$. Our experiment on the implementation lag allows for $h>0$. The household and firms will take some actions between $0 \leq t<h$ before $G_{t}$ actually increases. Obviously, when $h=0$, the fiscal stimulus is implemented without a lag.

To analyze the money-financed fiscal stimulus, we follow the literature and consider the government as a single consolidated entity consisting of the fiscal authority and the central bank. Let $M_{t}^{s}$ be the money supply. The government's consolidated budget constraint is

$$
P_{t} G_{t}+\left(1+I_{t-1}\right) B_{t-1}=P_{t} T_{t}+B_{t}+\Delta M_{t}^{s}
$$

where $\Delta M_{t}^{s}=M_{t}^{s}-M_{t-1}^{s}$. The left-hand side of (8) means that the government purchases the final goods $G_{t}$ and repays one-period government bonds with interest rate, $\left(1+I_{t-1}\right) B_{t-1}$. On the right-hand side of (8), the government collects the lump-sum taxes and issues new government bonds and noninterest-bearing money to finance its expenditure. Let us divide both sides of (8) by $P_{t}$ to obtain the consolidated budget constraint in real terms:

$$
G_{t}+R_{t-1} \mathcal{B}_{t-1}=T_{t}+\mathcal{B}_{t}+\Delta M_{t}^{s} / P_{t}
$$

where $R_{t}=\left(1+I_{t}\right) P_{t} / P_{t+1}$, and $\mathcal{B}_{t}=B_{t} / P_{t}$. In the equation, $\Delta M_{t}^{s} / P_{t}$ is real seigniorage revenue. We assume that $G_{t}$ and $T_{t}$ have their steady state values and seigniorage is zero in the steady state $\left(\Delta M_{t}^{s}=0\right)$. These assumptions imply that $G+R \mathcal{B}=T+\mathcal{B}$ in the steady state, where a variable without a subscript indicates the steady-state value. Let $\tau_{t}$ and $b_{t}$ be the lump-sum taxes and the issuance of real government bonds exceeding its own steady-state level expressed as a fraction of the steady-state output, respectively (i.e., $\tau_{t}=\left(T_{t}-T\right) / Y$, and $b_{t}=\left(\mathcal{B}_{t}-\mathcal{B}\right) / Y$.). We take the difference between $G+R \mathcal{B}=T+\mathcal{B}$ and $(9)$ and express the resulting equation as a fraction of the 
steady-state output. As a result, the linearly approximated consolidated budget constraint is

$$
b_{t}=R b_{t-1}+R b\left(i_{t-1}-\pi_{t}\right)+g_{t}-\tau_{t}-V^{-1} \Delta m_{t}^{s}
$$

where $b=\mathcal{B} / Y, i_{t}=\ln \left[\left(1+I_{t}\right) / R\right], \pi_{t}=\ln \left(P_{t} / P_{t-1}\right)$, and $\Delta m_{t}^{s}=\ln \left(M_{t}^{s} / M_{t-1}^{s}\right)$. Furthermore, $V$ is the steady-state value of the income velocity of money (given by $V_{t}=P_{t} Y_{t} / M_{t}^{s}$ ). The first and second terms of the right-hand side of (10) result from $\left(R_{t-1} \mathcal{B}_{t-1}-R \mathcal{B}\right) / Y \simeq R\left(\mathcal{B}_{t-1}-\mathcal{B}\right) / Y+$ $(\mathcal{B} / Y)\left(R_{t-1}-R\right) \simeq R b_{t}+R b\left(i_{t-1}-\pi_{t}\right)$. The last term is the linear approximation of the real seigniorage revenue around $\Delta M^{s}=0$ and $\pi=0$. More specifically, real seigniorage expressed as a fraction of the steady-state output is $\Delta M_{t}^{s} /\left(P_{t} Y\right)$ and can be approximated as

$$
\frac{\Delta M_{t}^{s}}{P_{t} Y}=\frac{\Delta M_{t}^{s}}{M_{t-1}^{s}} \frac{P_{t-1}}{P_{t}} \frac{M_{t-1}^{s}}{P_{t-1} Y} \simeq V^{-1} \Delta m_{t}^{s}
$$

We now define the money-financed fiscal stimulus as the monetization of government purchases satisfying:

$$
G_{t}-G=\frac{\Delta M_{t}^{s}}{P_{t}}
$$

That is, all government purchases exceeding its steady-state level is financed by the seigniorage. ${ }^{2}$ By dividing both sides by the steady-state output, we have $g_{t} \simeq \Delta m_{t}^{s} / V$ from (11). Therefore, the money supply under the money-financed fiscal stimulus is approximately determined by

$$
\Delta m_{t}^{s}=V g_{t}
$$

The lump-sum tax in (10) is specified by the following reaction function:

$$
\tau_{t}=\psi_{b} b_{t-1}
$$

Substituting (12) and (13) into (10), we have

$$
b_{t}=\left(R-\psi_{b}\right) b_{t-1}+b R\left(i_{t-1}-\pi_{t}\right) \text {, }
$$

\footnotetext{
${ }^{2}$ Galí (2017) considers a money-financed fiscal stimulus that keeps the issuance of government bonds unchanged in real terms. The money-financed fiscal stimulus considered here involves money creation that finances the government purchases in excess of its steady-state level. This is because Galí's (2017) specification often violates the BlanchardKahn condition, if it is combined with the CIA constraint. By contrast, ours robustly satisfies the Blanchard-Kahn condition regardless of our assumption about the money demand function.
} 
where we assume that $R-\psi_{b}<1$ to ensure the stability of $b_{t}$. The dynamics of the debt-to-GDP ratio here are residually determined from the system of equations under (12) and (13). In this model, $b_{t}$ is driven by the interest payment on the government debt and its persistence depends on how we specify $\psi_{b}$ in (13).

\subsection{Market clearing}

Equilibrium in the final goods market requires $Y_{t}=C_{t}+G_{t}$. The labor market clearing condition is $N_{t}=\int_{0}^{1} N_{t}(j) d j$ for all $t$. For the money market, we assume that the money supply fully determines the household's nominal holdings of money and $M_{t}^{s}=M_{t}$ holds for all $t$. This assumption is not inconsistent with an occasionally binding CIA constraint. If $I_{t}>0$ in equilibrium dynamics, the CIA constraint is binding and the household's desired level of money equals the money supply: $M_{t}=P_{t} C_{t}=M_{t}^{s}$. If $I_{t}=0$, the CIA constraint is not binding and not all of the money will be used to purchase goods: $M_{t}>P_{t} C_{t}$. Even if $I_{t}=0$, however, the money can still be used for transferring the household's wealth into the next period. Therefore, $M_{t}^{s}=M_{t}$ holds for all $t$. Likewise, the government bond market also clears as usual if $I_{t} \geq 0$. If $I_{t}=0$, the nominal bond holdings by the household are fully determined by the money supply in the economy.

\section{Results}

To assess the impact of the implementation lag of the money-financed fiscal stimulus on equilibrium dynamics, we use the (log) linearized version of the model around the zero inflation steady state. $^{3}$ We perform two experiments, based on two initial states of the economy: (i) normal times with $I_{t}>0$ and (ii) the liquidity trap with $I_{t}=0$. We conduct the first experiment particularly because it helps us better understand equilibrium dynamics in a liquidity trap. We then assess the effects of the length of the implementation lag and the interest semi-elasticity of money demand.

\subsection{Calibration}

For the simulations, we select $\beta=0.995, \sigma=1, \varphi=5, \alpha=1 / 4, \epsilon=9, \theta=3 / 4$, and $\psi_{b}=0.02$. These parameters are taken from Galí (2017) and all standard in the literature. Because inflation is zero in the steady state, $\beta=0.995$ implies that the annualized real interest rate is two percent in the steady state (i.e., $R=1.005$ ). The steady-state share of government purchases to output is 20

\footnotetext{
${ }^{3}$ The linearized equations are described in the Appendix A of this paper.
} 
percent (i.e., $\gamma=G / Y=0.2$ ), which is consistent with the U.S. data. ${ }^{4}$ By definition, the income velocity $V_{t}=\left(P_{t} Y_{t}\right) / M_{t}=\left[\left(P_{t} C_{t}\right) / M_{t}\right]\left(Y_{t} / C_{t}\right)$. Assuming that the CIA constraint in the steady state holds with equality, the steady-state income velocity is given by $V=Y / C=1 /(1-\gamma)=1.25$. In terms of implementation lag $h$, there seems no strong consensus about how long it takes for the government to implement their policy in general or how far in advance agents become aware of possible changes to the money-financed fiscal stimulus. For example, using the narrative-approach tax shock series of Romer and Romer (2010), Mertens and Ravn (2011) find that the median implementation lag is six quarters for a tax shock. Ramey (2011) argues that defense spending shocks identified by vector autoregressions using the postwar U.S. data are forecastable four quarters in advance. She also argues that even nondefense spending would be known at least a few months in advance. Therefore, we consider a relatively wide range of values of $h$ in the simulations. Taking these previous studies into account, we set $h=6$ as the benchmark and consider $h=1,4$, and 8 for robustness.

\subsection{The effect of the money-financed fiscal stimulus on output}

\subsubsection{Experiment I: The economy in normal times}

The first experiment considers the money-financed fiscal stimulus in normal times. More specifically, we assume that the economy for $t<0$ is initially in the steady state with $I_{t}>0$. Given this state of the economy, the money-financed fiscal stimulus is announced at $t=0$ and implemented at $t=h \geq 0$.

Figure 1 plots the output response to the money-financed fiscal stimulus with and without an implementation lag (denoted by " $h=6$ " and " $h=0$ " in the figure). The blue line indicates the output response when the money-financed fiscal stimulus is implemented immediately. In this case, the money-financed fiscal stimulus can also be understood as an unanticipated fiscal stimulus implemented at $t=0$. In response to this unanticipated fiscal stimulus, output exhibits a substantial expansion. In fact, when $g_{t}$ increases by one percent of the steady-state output, output in the same period increases by 1.40 percent, meaning that the government spending multiplier is larger than unity. The positive response is large because of expansionary fiscal policy and simultaneous monetary expansion.

The red line in Figure 1 indicates that, if the same fiscal stimulus is implemented with a lag,

\footnotetext{
${ }^{4}$ For example, see Erceg and Lindé (2014).
} 
the output responses differ dramatically from the previous case. In this case, the money-financed fiscal stimulus is announced at $t=0$ and the implementation at $t=6$ is credibly anticipated. In response to the announcement, output gradually decreases. That is, the money-financed fiscal stimulus causes a recession rather than a boom. The output decline is substantial at 0.77 percent immediately before the implementation. Once the fiscal stimulus is implemented at $t=6$, output responses become positive for $t \geq h$. However, when $g_{t}$ increases, output in the same period increases by only 0.87 percent (compared with the steady state value), implying the fiscal stimulus has a weaker effect.

The reason for the recession is straightforward. Aggregate demand is depressed by the increases in prices before the implementation of the money-financed fiscal stimulus. To better understand this, let us express the money and goods market equilibrium conditions in log-linearized form. The money market equilibrium condition is $c_{t}=m_{t}^{s}-p_{t}$ and the goods market equilibrium condition is $y_{t}=(1-\gamma) c_{t}+g_{t}$, where $m_{t}^{s}$ and $p_{t}$ represent the log-deviation from their (initial) values at $t=-1$. Also, $c_{t}$ and $y_{t}$ are the log-deviation from the steady state. Combining these two equations yields

$$
y_{t}=(1-\gamma)\left(m_{t}^{s}-p_{t}\right)+g_{t}
$$

By definition, $m_{-1}^{s}$ and $p_{-1}$ are zero. Therefore, $m_{t}^{s}$ and $g_{t}$ are also zero before the money-financed fiscal stimulus is implemented (i.e., $m_{t}^{s}=g_{t}=0$ for $t<h$ ). However, $p_{t}$ can change during the period between announcement and implementation (i.e., $0 \leq t<h$ ). In response to the announcement, forward-looking firms increase prices prior to the implementation. That is, higher aggregate demand in the future increases prices $p_{t}$. Therefore, we have

$$
y_{t}=-(1-\gamma) p_{t}<0
$$

for $0 \leq t<h$. This implies that the money-financed fiscal stimulus for $h>0$ causes a recession rather than a boom.

The mechanism behind the output reduction is the same as that discovered by Ball (1994) in the context of the credible announcement of disinflationary policy. Ball (1994) shows that the credible announcement of disinflationary monetary policy (i.e., an announcement of a decline in money growth) causes a boom rather than a recession in a sticky price model. In our model with fiscal policy, the announcement of the money-financed fiscal stimulus is equivalent to an announcement of inflationary policy, causing a recession rather than a boom. 
Figure 2 displays the responses of the other macroeconomic variables to the announcement of the fiscal stimulus with an implementation lag. As shown in the upper-right panel, inflation responds immediately to the announcement because of the forward-looking property of inflation. In the second row, consumption exhibits dynamic patterns similar to output, although the increase in consumption at the time of implementation is smaller than that in output. The nominal and real interest rates are volatile, peaking in period 5. Furthermore, the nominal interest rate is completely insensitive before the implementation, based on our calibrated degree of relative risk aversion of unity. ${ }^{5}$ This insensitive response of the nominal interest rate for $t<h$ is preserved even in the economy caught in a liquidity trap and thus the duration of ZLB spells is not substantially shortened by this fiscal stimulus.

\subsubsection{Experiment II: The economy in a liquidity trap}

The second experiment assesses the money-financed fiscal stimulus at the time of the liquidity trap. More specifically, the money-financed fiscal stimulus is announced at $t=0$ and implemented at $t=h \geq 0$ as before, but we assume that the government announces the money-financed fiscal stimulus when the economy is in the liquidity trap with $I_{t}=0$

To generate the initial state of the liquidity trap, we follow the literature and introduce a deterministic adverse demand shock. ${ }^{6}$ Here, the adverse demand shock appears in the log-linearized Euler equation:

$$
c_{t}=c_{t+1}-\sigma^{-1}\left(i_{t}-\pi_{t+1}-\rho_{t}\right)
$$

where $\rho_{t}=-\ln \left(Z_{t+1} / Z_{t}\right)$. We assume that the economy for $t<-1$ is in the steady state in which the central bank implements the optimal discretionary monetary policy. ${ }^{7}$ In period $t=-1, \rho_{t}$ decreases so that the nominal interest rate hits the ZLB. In particular, $\rho_{t}<\log \beta=-\log R$ for $-1 \leq t \leq T$ and $\rho_{t}=0$ for $t>T$. The decline in $\rho_{t}$ is unexpected at the beginning of $t=-1$, but once the decline is observed, the above path of $\rho_{t}$ is fully known. The value of $\rho_{t}$ is assumed to be constant over $t \in[-1, T]$ and is calibrated to generate a three-percent decline in output at the

\footnotetext{
${ }^{5}$ The response of the nominal interest rate $i_{t}$ can be seen from the log-linearized Euler equation in that period: $\Delta c_{t+1}=\sigma^{-1}\left(i_{t}-\pi_{t+1}\right)$. Before the implementation of the money-financed fiscal stimulus, the CIA constraint implies that $\Delta c_{t}=-\pi_{t}<0$ because $\Delta m_{t}^{s}=V g_{t}=0$ for $t<h$. As we calibrated $\sigma$ equal to unity, $\Delta c_{t}=i_{t-1}-\pi_{t}$ and $\Delta c_{t}=-\pi_{t}$ lead to the fully insensitive nominal interest rate: $i_{t-1}=0$ for $t<h$. Once the fiscal stimulus is implemented, $\Delta m_{t}^{s}>0$. In this case, we have $\Delta c_{t}=\Delta m_{t}^{s}-\pi_{t}>-\pi_{t}$ for $t \geq h$ resulting in $i_{t-1}=\Delta m_{t}^{s}>0$ for $t \geq h$.

${ }^{6}$ For example, see Jung, Teranishi and Watanabe (2005).

${ }^{7}$ As discussed in Galí $(2015,2017)$, the allocation under the discretionary monetary policy with the ZLB constraint is replicated by the Taylor rule, $i_{t}=\max \left(0, \rho_{t}+\phi_{\pi} \pi_{t}\right)$, where $\phi_{\pi}>1$.
} 
time of the decline in $\rho_{t}$. Given this decline in output, we examine how the government can help the economy recover from the recession, using the money-financed fiscal stimulus.

To measure the purified effect of the money-financed fiscal stimulus, we define the allocation with no policy change as the reference level. ${ }^{8}$ In this allocation, the central bank continues to implement the optimal discretionary monetary policy for $t \geq 0$. Conveniently, this allocation serves as the reference level in measuring the purified effect of the money-financed fiscal stimulus. If the ZLB constraint is not binding, the optimal discretionary monetary policy can fully stabilize both output and inflation because of the absence of cost-push shock. If the ZLB is binding, the optimal discretionary monetary policy cannot fully stabilize the output and inflation because of the central bank's failure to lower the nominal interest rate. Note that the assumptions that $\rho_{t}<\log \beta=-\log R$ for $-1 \leq t \leq T$ and that $\rho_{t}=0$ for $t>T$ ensure that the ZLB constraint is binding only for $-1 \leq t \leq T$ under the optimal discretionary monetary policy. The black dashed line in Figure 3 is the output response under this allocation with no policy change. In the figure, we set $T=5$ so that the decreased $\rho_{t}$ causes the liquidity trap during $-1 \leq t \leq 5$. Because of the ZLB on the nominal interest rate, output is lower than the steady state for $-1 \leq t \leq 5$ and is kept at the steady-state level for $t>5$.

Figure 3 compares the output responses to the announcement of a money-financed fiscal stimulus between $h=0$ and $h=6$. The red line shows that the fiscal stimulus for $h=6$ generates a slower recovery from recession than the reference level of no policy change. In other words, it causes a "recession" compared with the reference level. Similar to Experiment I, this is in sharp contrast to the case of $h=0$. As shown by the blue line, the money-financed fiscal stimulus without a lag achieves a faster recovery from the recession than the reference level (i.e., a "boom" compared with the reference level).

Note that, in Experiment II, the Euler equation matters for consumption rather than the CIA constraint. This is because the CIA constraint (5) is not binding when the nominal interest rate hits the ZLB. Given that the CIA constraint is not binding, (17) implies that the dynamic path of the real interest rate is important for consumption under $I_{t}=0$. In other words,

$$
c_{t}=-\sigma^{-1} \sum_{j=0}^{\infty}\left(r_{t+j}-\rho_{t+j}\right)
$$

where $r_{t}=i_{t}-\pi_{t+1}$.

\footnotetext{
${ }^{8}$ In Galí (2017), the allocation with no policy change is denoted as the benchmark case of no fiscal response.
} 
Figure 4 plots the impulse responses of the other macroeconomic variables under the liquidity trap. Here, the adverse demand shock $\rho_{t}$ (shown in the bottom row of the figure) is strong enough for the nominal interest rate to hit the ZLB (the third row of the figure) so inflation drops substantially (the first row). The shock to $\rho_{t}$ is common irrespective of the presence of the fiscal stimulus. As a result, the real interest rate is high during the first few periods (the left panel of the third row of the figure) in both the money-financed fiscal stimulus and no policy change scenarios. This high real interest rate reduces consumption in both cases.

To understand the mechanism behind the "recession" in Experiment II, we compare the real interest rate between the cases of the money-financed fiscal stimulus and no policy change. Comparisons reveal that the real interest rate under the money-financed fiscal stimulus roughly follows the reference level for $t<4$. However, the real interest rate under the money-financed fiscal stimulus exceeds the reference level substantially after $t=5$. In particular, the real interest rate at $t=5$ is 2.7 percentage points higher under the fiscal stimulus than under its reference level. The real interest rate, which is higher than the reference level for $t>5$, leads to weaker aggregate demand than in the reference level.

Therefore, the intuition is that future government purchases $g_{t}$ crowds out current consumption $c_{t}$ through the Euler equation. Likewise, $y_{t}$ is lower than the reference level for $0<t<h$ because only consumption is aggregate demand in these periods. Higher inflation expectations under the money-financed fiscal stimulus cause the nominal interest rate to exceed zero one period earlier than the case of no policy change. Consequently, the CIA holds with equality at $t=5$ and consumption in the subsequent periods is constrained by the CIA. At $t=5$, the reason that consumption is lower under the money-financed fiscal stimulus than its reference level is the same as in Experiment I. That is, because the aggregate prices are higher than the reference level, consumption becomes lower than the reference level.

We also note that, unlike the case of the money-financed fiscal stimulus in normal times, the debt-to-GDP ratio is uniformly higher under the money-financed fiscal stimulus with an implementation lag than under no policy change. Based on (14), a debt-to-GDP ratio higher than its reference level results from a higher real interest than the reference level.

\subsection{The role of the implementation lag}

Because there is no broad consensus on the length of the implementation lag of the moneyfinanced fiscal stimulus, it is useful to consider the output responses for different values of $h$. 
Figure 5 plots the output responses to the announcement of the money-financed fiscal stimulus when the length of implementation lag varies: $h=0,1,4,8$. In the upper panel of the figure, we assume that the policy is announced when the economy is initially in the steady state with $I_{t}>0$. In the lower panel, we assume that the policy is announced when the economy is in the liquidity trap with $I_{t}=0$. To facilitate comparison between the two cases, the output responses in the lower panel are expressed as output responses relative to the reference level of no policy change.

In both panels of Figure 5, the recession is more severe for a larger $h$. In the upper panel of the figure, each line exhibits the largest output decline in the period immediately before the implementation of the fiscal stimulus. The largest output decline is 0.41 percent for $h=1$ and 0.78 percent for $h=8$. In the lower panel, the largest output decline (relative to the reference level of no policy change) is 0.40 percent for $h=1$ and 0.84 percent for $h=8$. Furthermore, for $h=8$, we observe another large output decline at the time of the announcement of the money-financed fiscal stimulus, making our results stronger.

When the economy is initially in normal times, (16) holds for $0 \leq t<h$. Therefore, the recession becomes more severe as forward-looking firms have more opportunities to adjust their nominal prices upward prior to the implementation of the fiscal stimulus.

When the economy is in the liquidity trap, (18) matters for consumption for $0 \leq t<h$. Therefore, the "recession" relative to the reference level becomes more severe as the extent to which the real interest rate is higher than its reference level becomes greater. This relationship holds as long as $I_{t}=0$.

Figure 6 assumes that the economy is initially in the liquidity trap as in the lower panel of Figure 5 and numerically compares the extent to which the real interest rate exceeds its reference level. The figure shows that, as $h$ increases, the real interest rate is more likely to exceed the reference level of no policy change in response to the announcement of the money-financed fiscal stimulus. Each panel presents the dynamics of the real interest rate for $h=0,1,4,8$ and its reference level of no policy change. For $h=0$ in the upper-left panel, the real interest rate is uniformly lower than the reference level of no policy change. This implies that consumption exceeds its reference level (see (18)). Next, for $h=1$ in the upper-right panel, while the real interest rate is higher than the reference level at $t=0$, it is lower than the reference level afterward. Therefore, for $h=1$, while consumption falls below the reference level only at $t=0$, it again exceeds the reference level afterward. When $h=4$, the real interest rate at $t=3$ is 3.28 percent, or 2.90 percentage points higher than the reference level. Because of the differences of the real interest rate from the reference 
level, the forward-looking household reduces its consumption at $t=0$. As a result, output at $t=0$ declines substantially in comparison with the cases of $h=0$ and 1 . For the same reason, the output decline for $h=8$ is even larger. In fact, the real interest rate at $t=7$ is 5.33 percent, or 3.32 percentage points higher than the reference level.

\subsection{The role of the interest semi-elasticity of money demand}

The findings in the preceding subsections depend on how we specify the money demand function. More specifically, output declines during the periods between the announcement and the implementation of the money-financed fiscal stimulus result from the CIA constraint that leads to (15) and (16). When we replace the CIA by the money-in-the-utility (MIU) function, however, the policy implications may differ because of the presence of the interest semi-elasticity of money demand. In this subsection, we explore this possibility. ${ }^{9}$

To clarify the motivation of our analysis, let us consider the following log-linearized money demand function (together with the money market equilibrium):

$$
m_{t}^{s}-p_{t}=c_{t}-\eta i_{t}
$$

where $\eta>0$ denotes the interest semi-elasticity of money demand. Note that as suggested by Eggertsson and Woodford (2003) and Jung, Teranishi and Watanabe (2005), the standard MIU function without a satiation level of real money balances is not necessarily consistent with the ZLB on the nominal interest rate. For this reason, we assume the MIU function with a satiation level of real money balances and follow a convenient way of modeling money demand by English, Erceg and Ló pez-Salido (2017). While we leave the derivation of (19) to the Appendix B, this money demand function has nonzero $\eta$ which depends on how much the steady-state consumption velocity deviates from the consumption velocity evaluated at the satiation level of real money balances.

For simplicity, consider the case when the economy is in the steady state with $I_{t}>0$ at the time of the policy announcement. Using (19), (16) is now changed to

$$
y_{t}=-(1-\gamma) p_{t}+(1-\gamma) \eta i_{t},
$$

for $0 \leq t<h$. This implies that the money-financed fiscal stimulus does not necessarily cause

\footnotetext{
${ }^{9}$ We also conduct many robustness analyses for the parameters in the model, including the size of the output decline caused by the liquidity trap. As discussed in the not-for-publication appendix, our results in this paper are robust to the parameter changes.
} 
a recession. In fact, a boom takes place prior to the actual increase in government purchases, if $\eta i_{t}>p_{t}$ for $0 \leq t<h$. In other words, the policymakers could alleviate the recession, even if the money-financed fiscal stimulus has an implementation lag. A natural question is how large $\eta$ should be for them to successfully prevent the recession.

Figures 7 and 8 plot the output responses to the announcement of the money-financed fiscal stimulus under three values of $\eta$. In both figures, we newly introduce the output responses under $\eta=4$ and 7 along with the benchmark result under $\eta=0$. The left panel represents the case of $h=6$ while the right panel refers to the case of $h=0$ for comparison. In each panel, the black solid line corresponds to the case of $\eta=4$ while the blue solid line indicates the case of $\eta=7$. The first parameterization of the interest semi-elasticity $(\eta=4)$ is taken from Christiano, Eichenbaum and Evans (2005) who estimate the semi-elasticity in the medium-scale New Keynesian model based on the U.S. data over the period 1965:Q3-1995:Q2. ${ }^{10}$ The second parameterization $(\eta=7)$ comes from Ireland (2009) who estimates $\eta$ over the period 1980:Q1-2006:Q4. ${ }^{11}$ These sample periods are particularly important for our calibration, because the data during the ZLB periods are explicitly excluded. In our model, when the ZLB constraint is binding, the household's real money holdings exceed the amount that it desires according to its money demand function. That is, $m_{t}^{s}-p_{t}>c_{t}-\eta i_{t}$ during the ZLB periods. If $\eta$ is estimated under the assumption that (19) always holds with equality, the data including the ZLB periods may not be appropriate for calibration.

Figure 7 assumes that the economy is in the steady state at the time of the announcement of the money-financed fiscal stimulus. The left panel of the figure reconfirms the predictions from (20). In the simulation, $i_{t}>0$ for $0 \leq t<h$. Therefore, whether a recession takes place prior to the implementation depends on $\eta$. As the black solid line of the left panel indicates (i.e., $\eta=4 \&$ $h=6)$, the responses are small in magnitude. This is because the effect of $\eta i_{t}$ cancels out the effect of $p_{t}$. Therefore, the recession, if any, is not as deep under $\eta=4$ as under $\eta=0$. When $\eta=7$ and $h=6$ (the blue solid line in the left panel), the former tends to dominate the latter so that the recession does not take place. We also note that the sensitivity to $\eta$ is observed only for $h=6$ : if there is no implementation lag, the money-financed fiscal stimulus is effective in increasing output.

In Figure 8, the economy is assumed to be in the liquidity trap at the time of the announcement.

\footnotetext{
${ }^{10}$ More precisely, they report that the interest semi-elasticity of money demand to the annualized interest rate is 0.96. Transforming this annualized interest semi-elasticity to the quarterly interest rate yields $\eta=3.84 \simeq 4$.

${ }^{11} \mathrm{He}$ estimates the annualized interest semi-elasticity to range between 1.5 and 1.9. Translating this range in terms of the quarterly rate, it is between 6.0 and 7.6.
} 
When $\eta=4$ and $h=6$, the output response follows a path similar to the reference level of no policy change prior to the implementation. In this case, output under $\eta=4$ is slightly lower than the reference level of output. When $\eta$ increases to 7 , the slow recovery from the recession disappears. In other words, the money-financed fiscal stimulus is effective even with an implementation lag. Nevertheless, the money-financed fiscal stimulus with an implementation lag achieves a much slower recovery to the steady state than that without an implementation lag (see the right panel of the same figure for the case of $h=0)$.

The responses of the other macroeconomic variables to the announcement under the liquidity trap are shown in Figure 9 to highlight the differences between the cases of $\eta=0$ and $\eta>0$. As shown in the third row of the figure, the nominal interest rate under $\eta=0$ equals zero until $t=5$. Because the household is indifferent between money and government bonds under $I_{t}=0$, it holds the money balances supplied by the central bank for the purpose of transferring its wealth into the next period. Because consumption is low, inflation remains low and the real interest rate remains high. The high real interest rate causes high interest payments of the government, so the debt-to-GDP ratio continues to increase.

By contrast, the model dynamics are very different under $\eta=7$. The nominal interest rate becomes positive at the time of the announcement at $t=0$. The economy escapes from the liquidity trap and (19) holds with equality at and after $t=0$. The nominal interest rate higher than zero incentivizes the household not to hold money balances as a substitute for government bonds. Real money holdings are reduced by the purchase of goods. As a result, consumption increases. In fact, the second row of Figure 9 indicates that consumption under $\eta=7$ increases beyond the reference level. Likewise, inflation under $\eta=7$ exceeds its reference level, as shown in the first row of the same figure. Such high inflation immediately lowers the real interest rate below the reference level. The low real interest rate contributes to decreasing the interest payments of the government, so the debt-to-GDP ratio is lower than the reference level and even starts to decline around the time of the implementation.

The policy implications of our analysis for the money-financed fiscal stimulus are threefold. First, if the money-financed fiscal stimulus has an implementation lag, policymakers should possess detailed knowledge on the money demand function. Without this knowledge, they may fail to achieve a fast recovery from the recession in response to an adverse demand shock. Second, if they are faced with a low interest semi-elasticity of money demand, they should use a moneyfinanced fiscal stimulus as immediately as possible. If policymakers do not give forward-looking 
households and firms many opportunities to make their decisions prior to the implementation of the money-financed fiscal stimulus, they can prevent the slower recovery of output. Finally, if they face difficulties in shortening implementation lags, the money-financed fiscal stimulus would be a reasonable policy option only when the interest semi-elasticity of money demand is sufficiently large.

\section{Concluding remarks}

Using the standard New Keynesian framework with nominal rigidities, we analyzed the effect of a money-financed fiscal stimulus with an implementation lag on output. The introduction of implementation lags that are specific to fiscal policy may have nonnegligible impacts on the output response to a shock in government purchases. While the money-financed fiscal stimulus has a strongly positive effect on output in the absence of an implementation lag, such a fiscal stimulus may have a weak or even negative effect on output if a reasonably long implementation lag exists. ${ }^{12}$ We showed that a shorter implementation lag makes the money-financed fiscal stimulus more effective. Our analysis also indicated that the effect of the money-financed fiscal stimulus varies, depending on the interest semi-elasticity of money demand. ${ }^{13}$ An implication for policymakers is that detailed knowledge of the money demand function is important for a better understanding of the efficacy of a money-financed fiscal stimulus. In this regard, empirical studies on the money demand function that explicitly allows for the ZLB constraint are also important. ${ }^{14}$

\footnotetext{
${ }^{12}$ Negative impacts of an implementation lag are related to the Fujiwara and Waki's (2015) finding that the social welfare in the standard New Keynesian model reduces as the private sector is well informed about the future fundamental shocks. See Fujiwara and Waki (2015) for additional details.

${ }^{13}$ The importance of the money demand function for the efficacy of fiscal policy was also pointed out by Holmes and Smyth (1972) and Mankiw and Summers (1986), based on the old-fashioned Keynesian IS-LM model. However, they emphasize the roles of the scale variable (e.g., consumption vs. income) in the money demand function.

${ }^{14}$ Some early examples of research include Bae, Kakkar and Ogaki (2006), Bae and de Jong (2007), and Nakashima and Saito (2012), among others.
} 


\section{References}

[1] Bae, Y. and R. M. de Jong (2007). "Money Demand Function Estimation by Nonlinear Cointegration," Journal of Applied Econometrics, 22 (4), 767-793.

[2] Bae, Y., V. Kakkar and M. Ogaki (2006). "Money Demand in Japan and Nonlinear Cointegration," Journal of Money, Credit, and Banking, 38 (6), 1659-1667.

[3] Ball, L. (1994). "Credible Disinflation with Staggered Price-Setting," American Economic Review, 84 (1), 282-289.

[4] Christiano, L. J., M. Eichenbaum and C. L. Evans (2005). "Nominal Rigidities and the Dynamic Effects of a Shock to Monetary Policy," Journal of Political Economy, 113 (1), 1-45.

[5] Cwik, T. and V. Wieland (2011). "Keynesian Government Spending Multipliers and Spillovers in the Euro Area," Economic Policy, 26 (67), 493-549.

[6] Eggertsson, G. B. and M. Woodford (2003). "The Zero Bound on Interest Rates and Optimal Monetary Policy," Brookings Papers on Economic Activity, 2003 (1), 139-233.

[7] English, W. B., C. J. Erceg and D. López-Salido (2017). "Money-Financed Fiscal Programs: A Cautionary Tale," Hutchins Center Working Paper No. 31.

[8] Erceg, C. and J. Lindé (2014). "Is There a Fiscal Free Lunch in a Liquidity Trap?" Journal of the European Economic Association, 12 (1), 73-107.

[9] Fujiwara, I. and Y. Waki (2015). "Private News and Monetary Policy Forward Guidance or (The Expected Virtue of Ignorance)," Federal Reserve Bank of Dallas Globalization and Monetary Policy Institute Working Paper No. 238.

[10] Fujiwara, I. and Y. Waki (2017). "Fiscal Forward Guidance: A Case for Selective Transparency," RIETI-Discussion Paper Series 17-E-087.

[11] Galí, J. (2015). Monetary Policy, Inflation, and the Business Cycle, Princeton University Press, Princeton NJ.

[12] Galí, J. (2017). "The Effects of a Money-Financed Fiscal Stimulus," University of Pompeu Fabra Economic Working Paper Series, Working Paper No. 1441. 
[13] Holmes, J. M. and D. J. Smyth (1972). "The Specification of the Demand for Money and the Tax Multiplier," Journal of Political Economy, 80 (1), 179-185.

[14] Ireland, P. N. (2009). "On the Welfare Cost of Inflation and the Recent Behavior of Money Demand," American Economic Review, 99 (3), 1040-1052.

[15] Jung, T., Y. Teranishi and T. Watanabe (2005). "Optimal Monetary Policy at the ZeroInterest-Rate Bound," Journal of Money, Credit and Banking, 37 (5), 813-835.

[16] Leeper, E. M., T. B. Walker and S.-C. S. Yang (2010). "Government Investment and Fiscal Stimulus," Journal of Monetary Economics, 57 (8), 1000-1012.

[17] Leeper, E. M. A. W. Richter and T. E. Walker (2010). "Quantitative Effect of Fiscal Foresight," NBER Working Paper No. 16363.

[18] Mankiw N. G. and L. H. Summers (1986). "Money Demand and the Effects of Fiscal Policies," Journal of Money, Credit and Banking, 14 (1), 27-54.

[19] Mertens, K. and M. O. Ravn (2011). "Understanding the Aggregate Effects of Anticipated and Unanticipated Tax Policy Shocks," Review of Economic Dynamics, 14 (1), 27-54.

[20] Nakashima, K. and M. Saito (2012). "On the Comparison of Alternative Specifications for Money Demand: The Case of Extremely Low Interest Rate Regimes in Japan," Journal of the Japanese and International Economies, 26 (3), 454-471.

[21] Ramey, V. A. (2011). "Identifying Government Spending Shocks: It's All in the Timing," Quarterly Journal of Economics, 126 (1), 1-50.

[22] Romer, C. D. and D. H. Romer (2010). "The Macroeconomic Effects of Tax Changes: Estimates Based on a New Measure of Fiscal Shocks," American Economic Review, 100 (3), 763-801.

[23] Turner A. (2015). "The Case for Monetary Finance - An Essentially Political Issue," presented at the 16th Jacques Polak Annual Research Conference, the International Monetary Fund, November 5-6, 2015.

[24] Yang, S. S.-C. (2005). "Quantifying Tax Effects under Policy Foresight," Journal of Monetary Economics, 52 (8), 1557-1568. 


\section{A The system of linearized equations}

The system of linearized equations is standard except that the CIA constraint is occasionally binding. The equation for the money growth rate follows (12). The other equations in the system are the same as Galí (2017).

Aggregate consumption of the households follows the Euler equation:

$$
c_{t}=c_{t+1}-\sigma^{-1}\left(i_{t}-\pi_{t+1}-\rho_{t}\right)
$$

as we discussed in the main text. Inflation evolves as

$$
\pi_{t}=\beta \pi_{t+1}-\lambda \mu_{t}
$$

where $\lambda \equiv[(1-\theta)(1-\beta \theta) / \theta][(1-\alpha) /(1-\alpha+\epsilon \alpha)]$. In the above equation, $\mu_{t}$ is the average price markup given by

$$
\mu_{t}=-\sigma c_{t}-\frac{\alpha+\varphi}{1-\alpha} y_{t}
$$

Note that the money demand function is given by the CIA constraint:

$$
l_{t} \geq c_{t}
$$

where $l_{t}=m_{t}-p_{t}$ is the real money holdings of the household. This equation holds with equality if $I_{t}>0$. We also have the law of motion for real money balances:

$$
l_{t}=l_{t-1}+\Delta m_{t}^{s}-\pi_{t}
$$

If the CIA constraint is not binding (or $I_{t}=0$ ), then (A4) is not used for computing the allocation. Instead, we use

$$
i_{t}=-\ln R
$$

implying that the household passively holds money based on the money supply.

The equilibrium condition for the final goods market is

$$
y_{t}=(1-\gamma) c_{t}+g_{t},
$$


where $g_{t}$ is exogenously given by (7). Because government purchases are financed by seigniorage, the money supply is automatically determined by

$$
\Delta m_{t}^{s}=V g_{t}
$$

Due to the reaction function for the lump-sum tax rule $\tau_{t}=\psi_{b} b_{t-1}$ and the above money supply process, the equation for the debt-to-GDP ratio reduces to

$$
b_{t}=\left(R-\psi_{b}\right) b_{t-1}+b R r_{t-1}
$$

where $r_{t}$ is the real interest rate given by the Fisher equation:

$$
r_{t}=i_{t}-\pi_{t+1}
$$

The system of equations consists of the endogenous variables, $y_{t}, c_{t}, i_{t}, r_{t}, \pi_{t}, l_{t}, \Delta m_{t}^{s}$, $b_{t}$, and $m u_{t}$. If $I_{t}>0$ and the CIA constraint is binding, the model can be solved by (A1)-(A5) and (A7)-(A10) in which (A4) holds with equality. If $I_{t}=0$ and the CIA constraint is not binding, (A4) must be replaced by (A6). Whether or not the CIA constraint is binding depends on the complementary slackness condition: $\left(l_{t}-c_{t}\right)\left(i_{t}-\ln R\right)=0, l_{t}-c_{t}>0$, and $i_{t}-\ln R>0$. For this complementary slackness condition, see also Galí (2017).

\section{B The model with the MIU function}

To derive money demand that is correlated with the nominal interest rate and is compatible with the ZLB on the nominal interest rate, the literature has assumed an MIU function with a satiation level of liquidity (see Eggertsson and Woodford, 2003). This is because, if the marginal utility of real money balances is strictly positive, the standard optimality condition rules out the possibility of $I_{t}=0$ in equilibrium (given the finite marginal utility of consumption).

English, Erceg, and López-Salido (2017) propose a convenient way of modeling money demand. Following their approach, we redefine the representative instantaneous utility function and re-

place $U\left(C_{t}, N_{t}\right)$ by $\tilde{U}\left(C_{t}, N_{t}, M_{t} / P_{t}\right)=\left[C_{t}^{1-\sigma} /(1-\sigma)-N_{t}^{1+\varphi} /(1+\varphi)+h\left(M_{t} / P_{t}\right)\right] Z_{t}$. Using a 
quadratic function, we specify the function $h(\cdot)$ as follows:

$$
h\left(\frac{M_{t}}{P_{t}}\right)=-\frac{\eta_{0}}{2}\left[\max \left(0, k^{*}-\frac{M_{t} / P_{t}}{\bar{C}_{t}}\right)\right]^{2} Z_{t},
$$

where $k^{*}$ is the satiation level of real money balances and $\bar{C}_{t}$ is the aggregate consumption that is taken as given by the representative household and that equals the household's consumption in equilibrium. Although admittedly ad hoc, this function is convenient for analyzing the model with the ZLB for at least two reasons. First, $h\left(M_{t} / P_{t}\right)$ reduces to a simple quadratic utility function if $\left(M_{t} / P_{t}\right) / \bar{C}_{t}<k^{*}$ is satisfied for any $t$. In this case, the marginal utility of real balances is strictly positive and thus the nominal interest rate is strictly positive. Second, $h\left(M_{t} / P_{t}\right)=0$ and $h^{\prime}\left(M_{t} / P_{t}\right)=0$ if the money supply is sufficiently large so that $\left(M_{t}^{s} / P_{t}\right) / \bar{C}_{t}=\left(M_{t} / P_{t}\right) / \bar{C}_{t} \geq k^{*}$. In this case, the nominal interest can be zero and money becomes a perfect substitute as an asset for transferring wealth into the next period.

Because we replace the CIA constraint by the money demand function based on the MIU function, we change the budget constraint slightly. In particular, we replace $P_{t-1} C_{t-1}$ in (1) by $P_{t} C_{t}$ :

$$
M_{t}+B_{t}=\left(1+I_{t-1}\right) B_{t-1}+M_{t-1}-P_{t} C_{t}+W_{t} N_{t}+P_{t} D_{t}-P_{t} T_{t}
$$

In contrast with (1), the nominal expenditure on the final goods is financed by the resource received in the same period rather than by the money holdings carried over from the previous period.

Assuming that $\left(M_{t} / P_{t}\right) / \bar{C}_{t}<k^{*}$, we replace (5) by

$$
\frac{h_{t}^{\prime}}{U_{C, t}}=\frac{I_{t}}{1+I_{t}}
$$

where $h_{t}^{\prime} \equiv h^{\prime}\left(M_{t} / P_{t}\right)=\eta_{0}\left[k^{*}-\left(M_{t} / P_{t}\right) / \bar{C}_{t}\right]\left(Z_{t} / \bar{C}_{t}\right)$. Furthermore, let $k_{t} \equiv\left(M_{t} / P_{t}\right) / C_{t}$ be the inverse of the consumption velocity of money. Let $k$ be the steady-state value of $k_{t}$. We assume that $k$ satisfies $k<k^{*}$. Along with the money market clearing condition and the assumption of $\sigma=1$, (B3) can be log-linearized as (19), where $\eta=\left(k^{*} / k-1\right)(R-1)^{-1}=\left(k^{*} / k-1\right)[\beta /(1-\beta)]$. Or equivalently, denoting the consumption velocity of money $V_{c}=k^{-1}$, we have

$$
\eta=\left(\frac{V_{c}}{V_{c}^{*}}-1\right) \frac{\beta}{1-\beta} .
$$

In this specification of the MIU function, the distance of the steady-state consumption velocity of 
money from the consumption velocity at which real money balances are satiated affects the interest semi-elasticity of money demand.

The other first-order conditions and resource constraints remain unchanged in solving the model. As before, the ZLB needs to be considered with the money market equilibrium condition. In particular, if $I_{t}>0$, the household's desired level of money holdings equals the money supply and $m_{t}^{s}-p_{t}=c_{t}-\eta i_{t}$ holds. If $I_{t}=0$ (or equivalently $i_{t}=-\ln R$ ), however, the money holdings may not be equal to their desired level and money is held as a perfect substitute for the oneperiod government bond. In this case, we compute the solution using $i_{t}=-\ln R$ instead of $m_{t}^{s}-p_{t}>c_{t}-\eta i_{t}$. 
Figure 1: Output responses to the announcement of the money-financed fiscal stimulus: Normal times

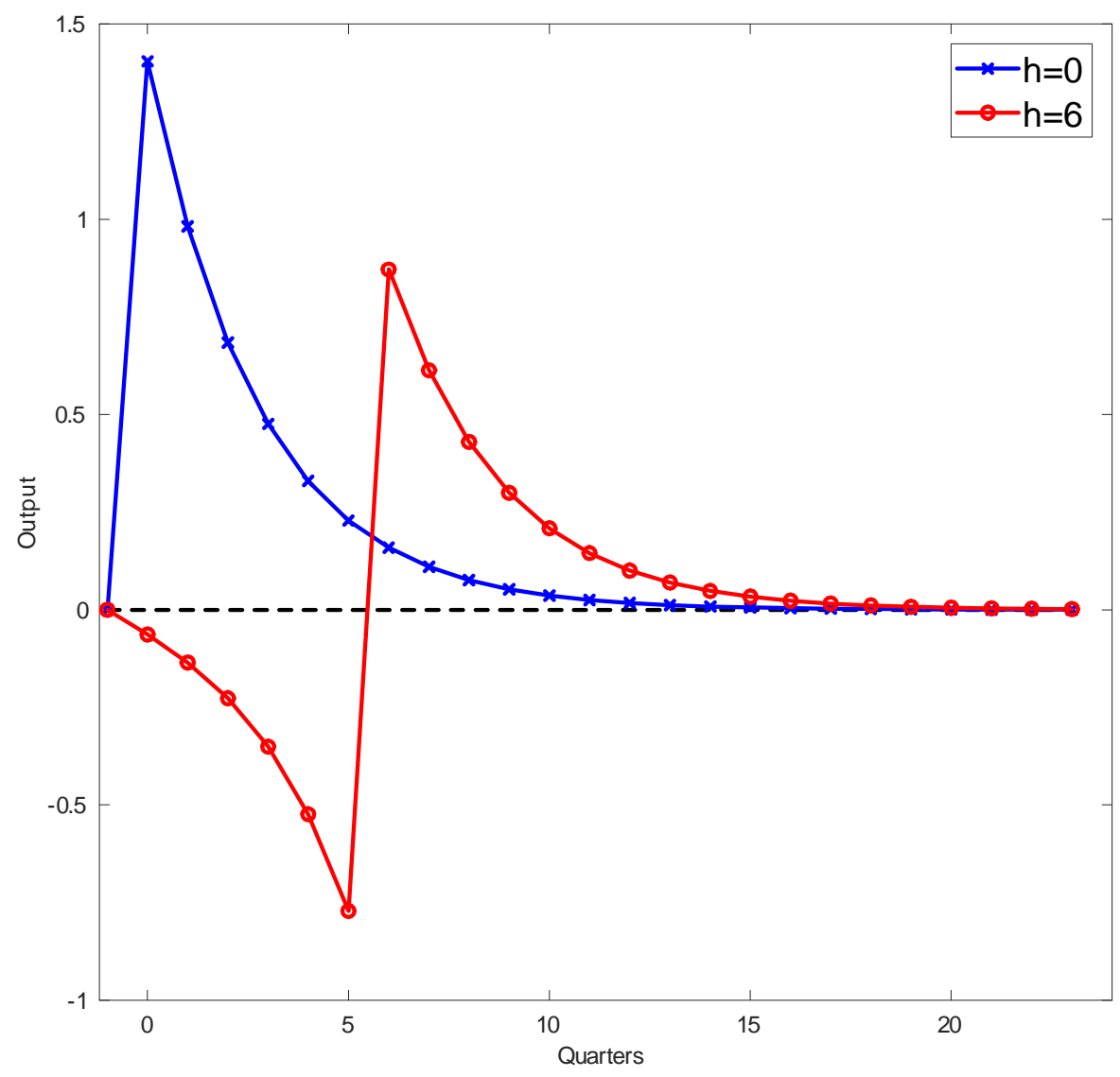

Notes: The money-financed fiscal stimulus is announced in period 0 and implemented in period $h$. The initial increase in government purchases is normalized to one percent of the steady-state output and government purchases are financed by money creation specified by (12). The blue line represents the case of $h=0$ while the red line corresponds to the case of $h=6$. Each period is a quarter. 
Figure 2: Responses to the announcement of the money-financed fiscal stimulus for $h=6$ : Normal times
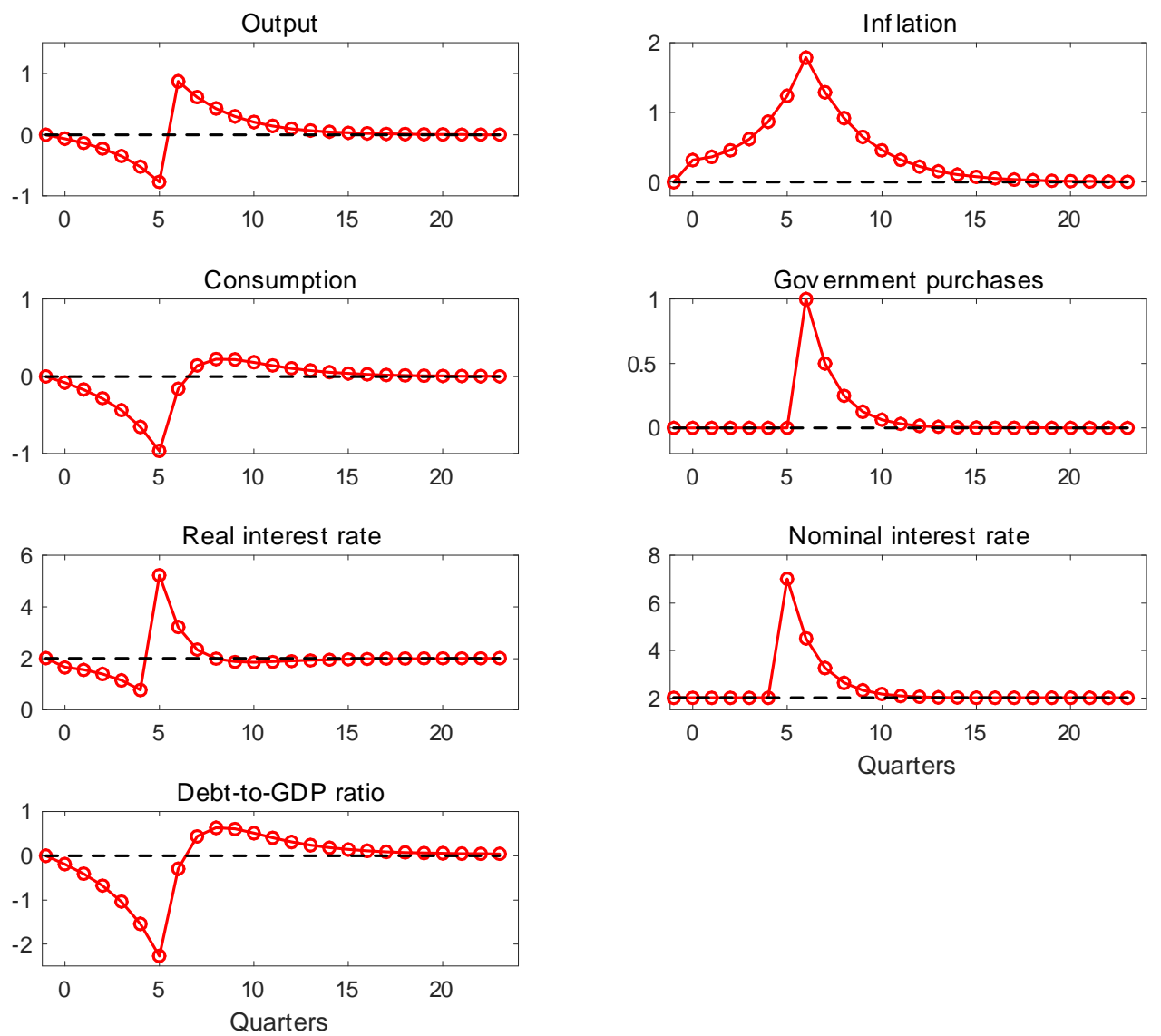

Notes: Inflation, the nominal interest rate, and the real interest rate are expressed at the annual rate. They are drawn as the variation around their steady-state values of two percent (for the nominal interest rate and the real interest rate) and zero percent (for inflation). While output and consumption are expressed as the log-deviation from the steady state, government purchases and the debt-to-GDP ratio are expressed as the difference from the steady state measured as a fraction of the steady-state output. See the notes to Figure 1 for additional details. 
Figure 3: Output responses to the announcement of the money-financed fiscal stimulus: Liquidity trap

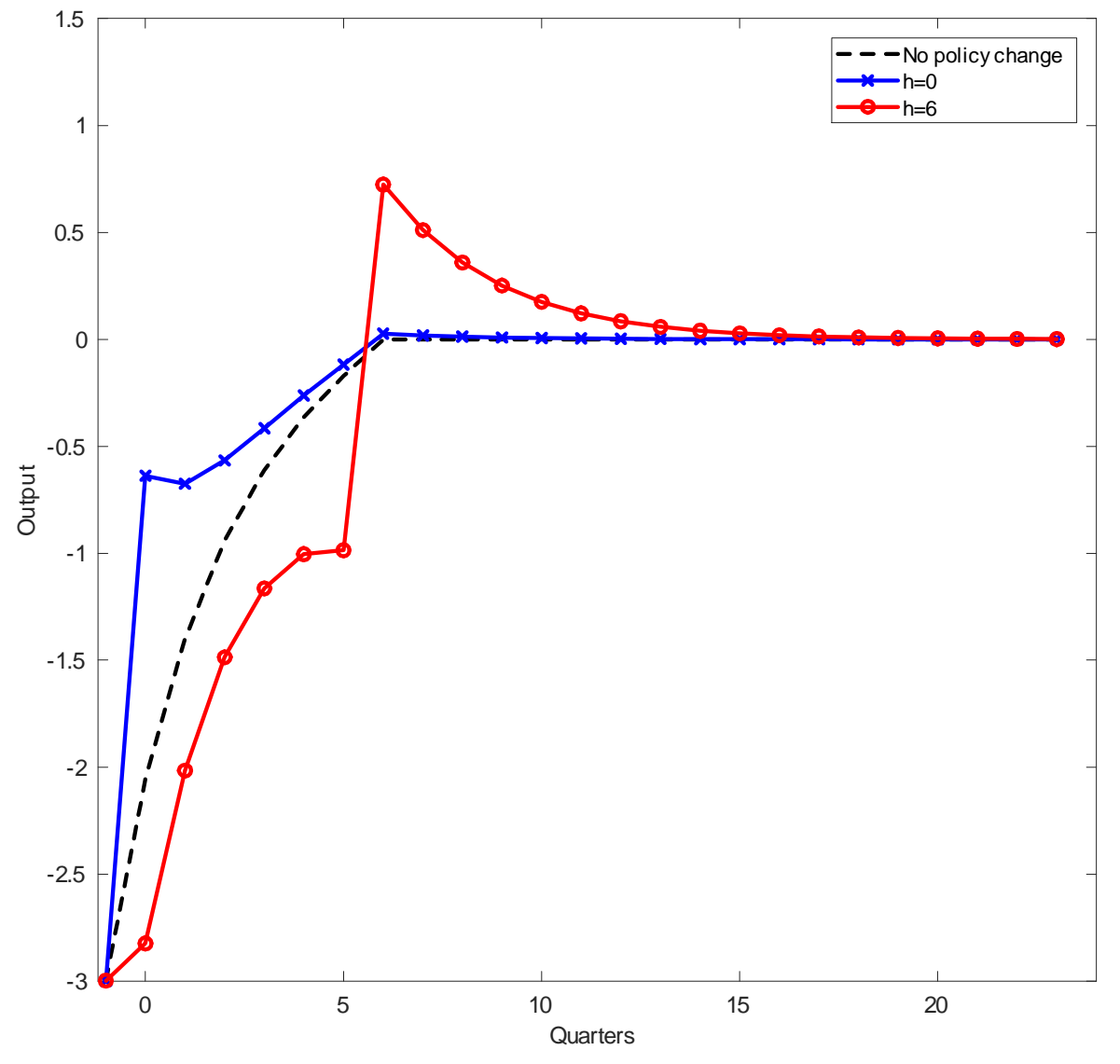

Notes: The money-financed fiscal stimulus is announced when the economy is in the liquidity trap with $I_{t}=0$. The dashed black line shows the reference level of output where the central bank continues to implement the optimal discretionary monetary policy and makes no policy change. See the notes to Figure 1 for additional details. 
Figure 4: Responses to the announcement of the money-financed fiscal stimulus for $h=6$ : Liquidity trap
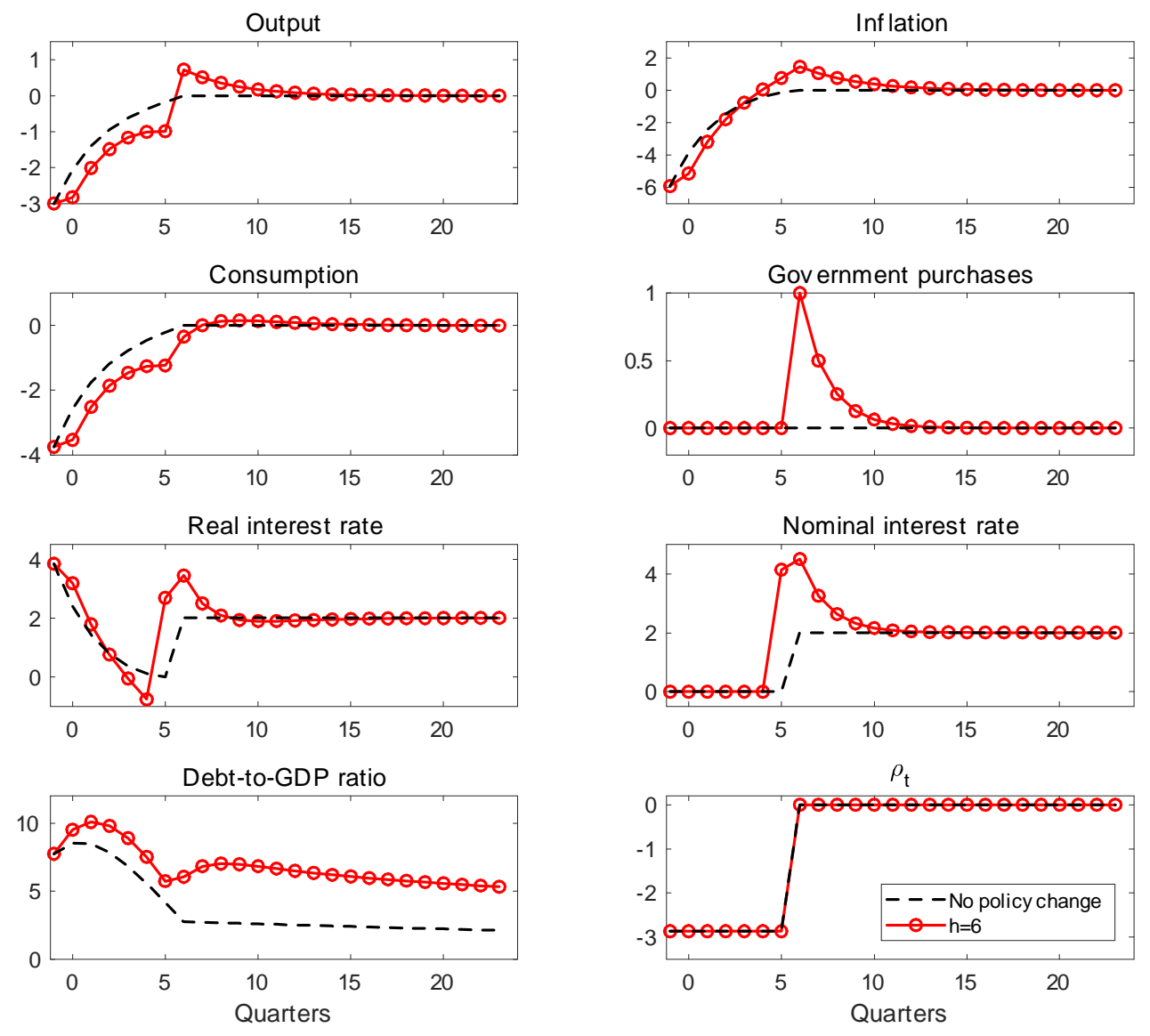

Notes: The money-financed fiscal stimulus is announced when the economy is in the liquidity trap with $I_{t}=0$. The dashed black line shows the reference level of output where the central bank continues to implement the optimal discretionary monetary policy and makes no policy change. See the notes to Figures 1 and 2 for additional details. 
Figure 5: Effects of implementation lags on output responses: Normal times and liquidity trap
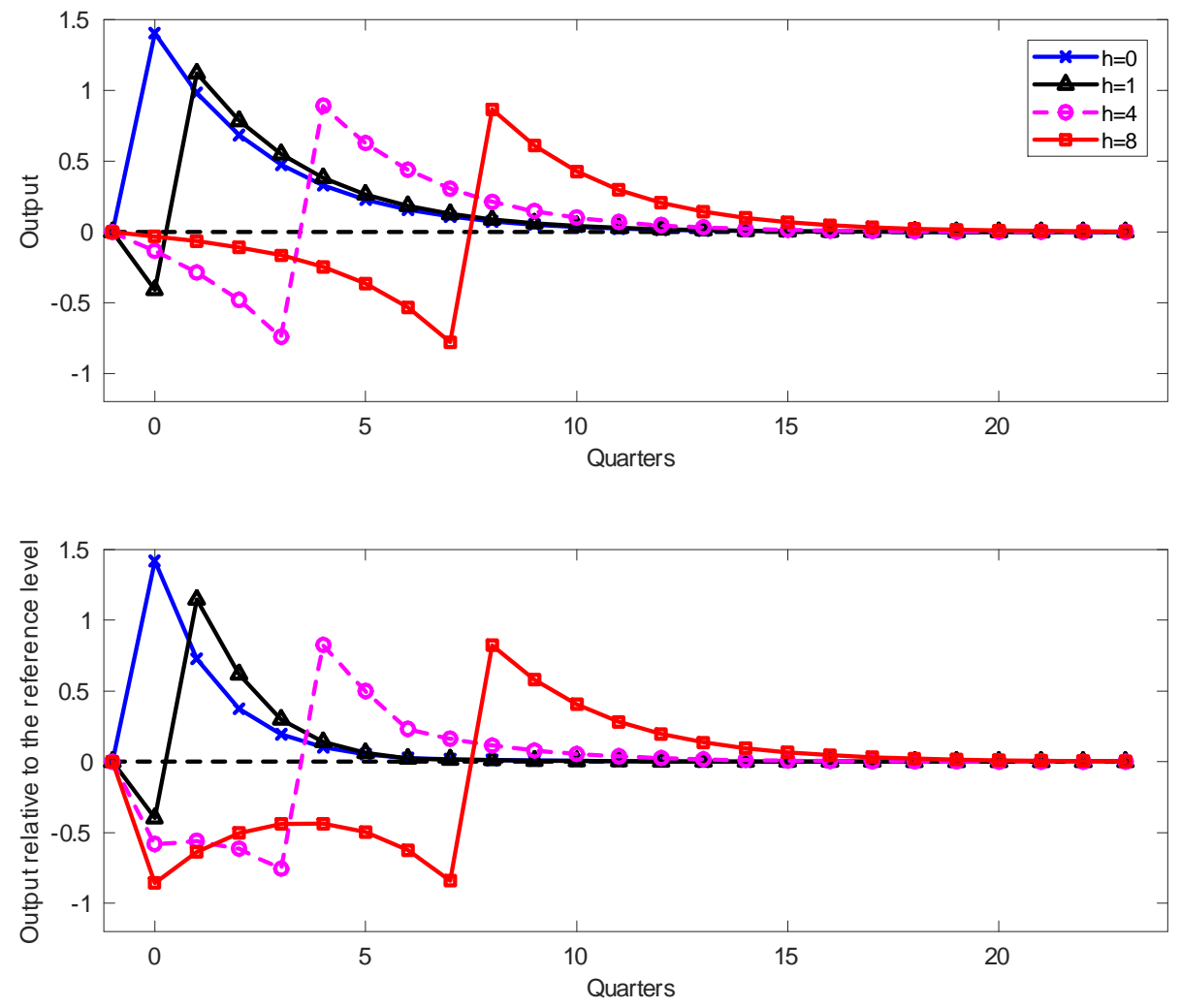

Notes: Both panels compare the responses of output for $h=0,1,4,8$. The solid blue line, the solid black line, the dashed purple line, and the solid red line correspond to the case of $h=0,1,4,8$, respectively. The upper panel assumes that the money-financed fiscal stimulus is announced when the economy is in the steady state with $I_{t}>0$. In the upper panel, each line shows the log-deviation of output from the steady state. The lower panel assumes that the money-financed fiscal stimulus is announced when the economy is in the liquidity trap with $I_{t}=0$. In the lower panel, each line shows the log-deviation of output from its reference level of no policy change where the central bank continues to implement the optimal discretionary monetary policy. See the notes to Figure 1 for additional details. 
Figure 6: Responses of the real interest rate under different values of $h$
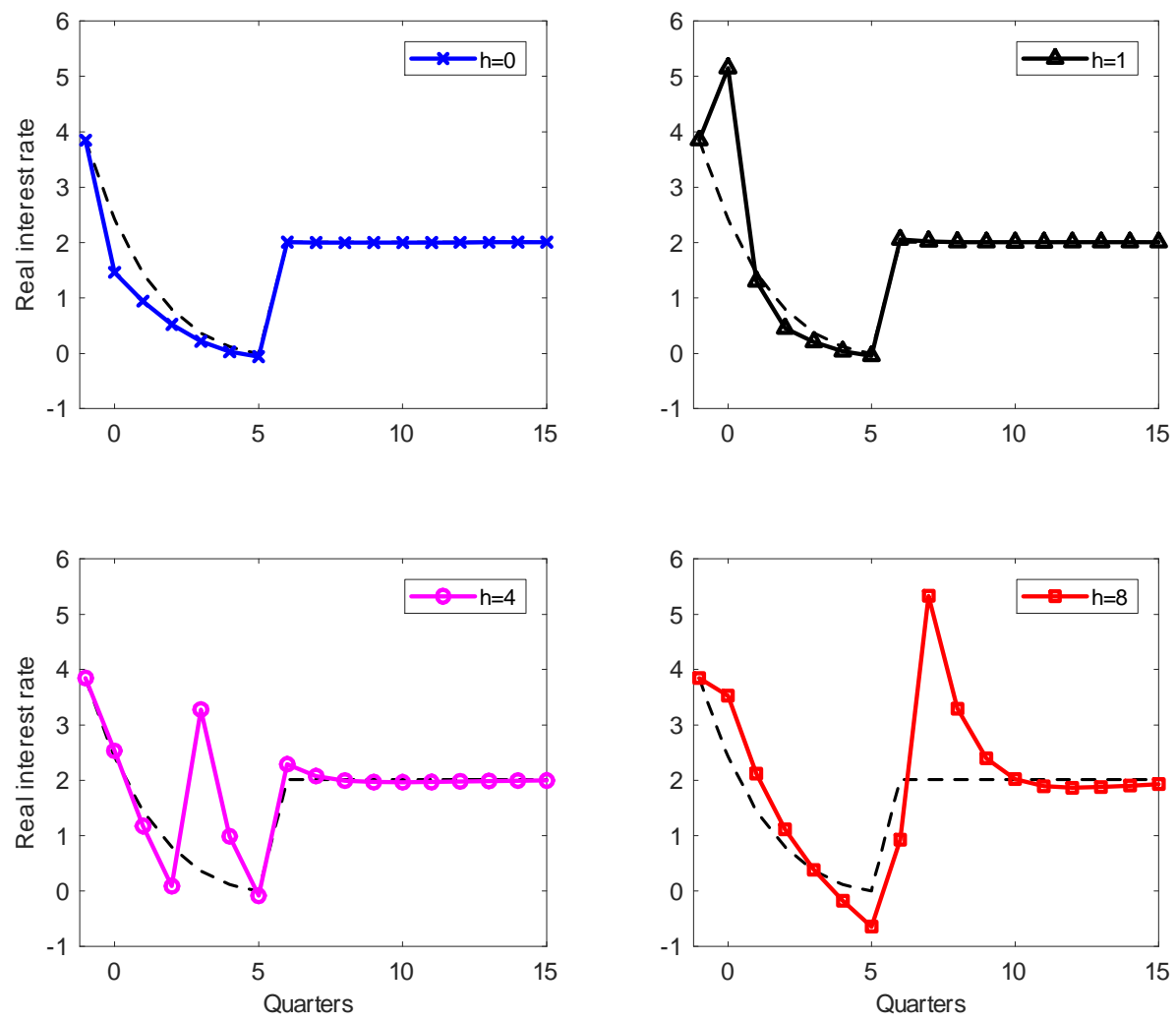

Notes: Responses of the real interest rate are shown for $h=0,1,4,8$. The money-financed fiscal stimulus is announced when the economy is in the liquidity trap with $I_{t}=0$. The real interest rate is expressed at the annual rate. The dashed black line shows the reference level where the central bank continues to implement the optimal discretionary monetary policy and makes no policy change. See the notes to Figures 1 and 5 for additional details. 
Figure 7: Effects of the interest semi-elasticity of money demand on output responses: Normal times
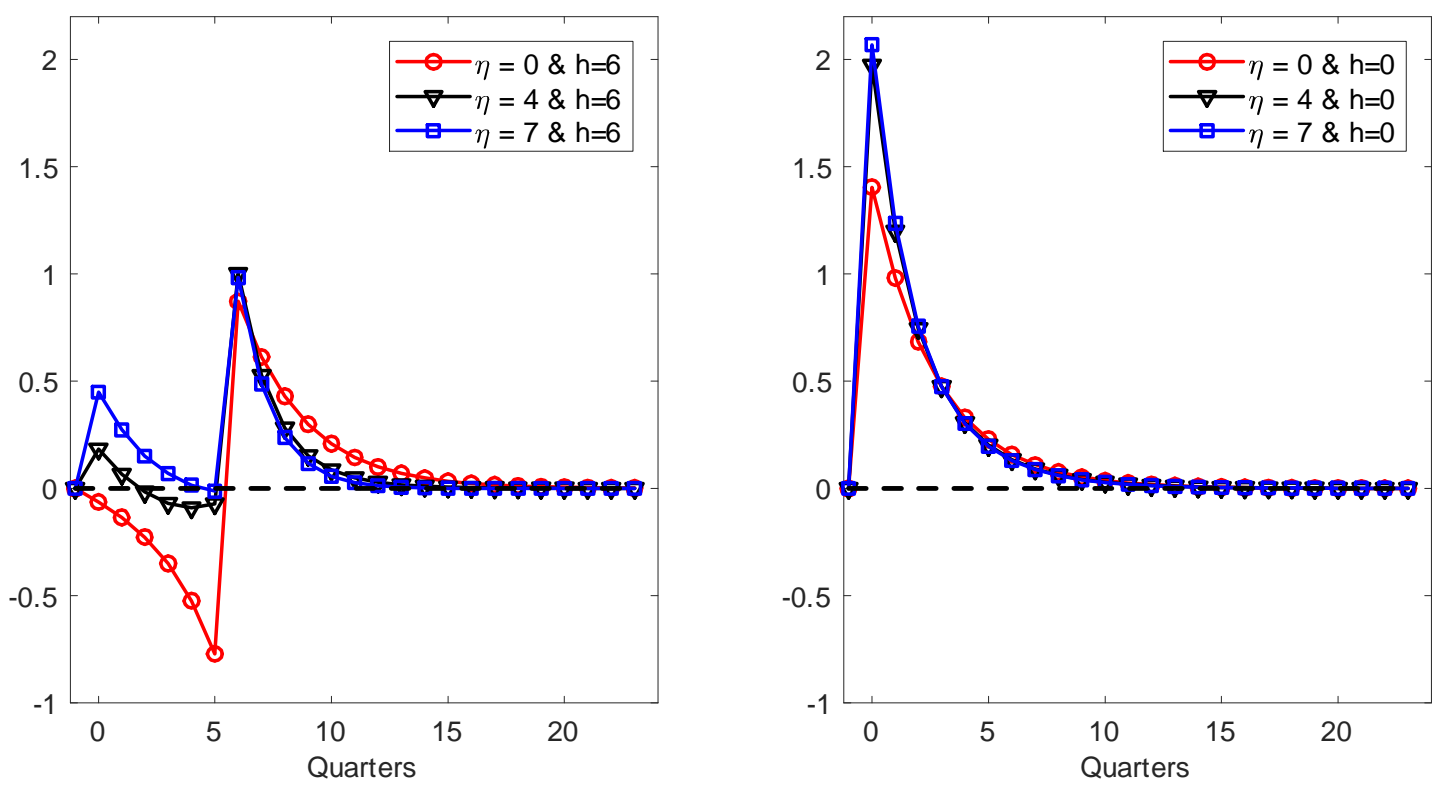

Notes: Output responses are based on the money demand function with the interest semi-elasticity of money demand $(\eta=0,4,7)$. The solid red line, the solid black line, and the solid blue line correspond to the case of $\eta=0,4,7$, respectively. The left panel shows the case of $h=6$ while the right panel shows the case of $h=0$. In each panel, the money-financed fiscal stimulus is announced when the economy is in the steady state with $I_{t}>0$. See the notes to Figure 1 for additional details. 
Figure 8: Effects of the interest semi-elasticity of money demand on output responses: Liquidity trap
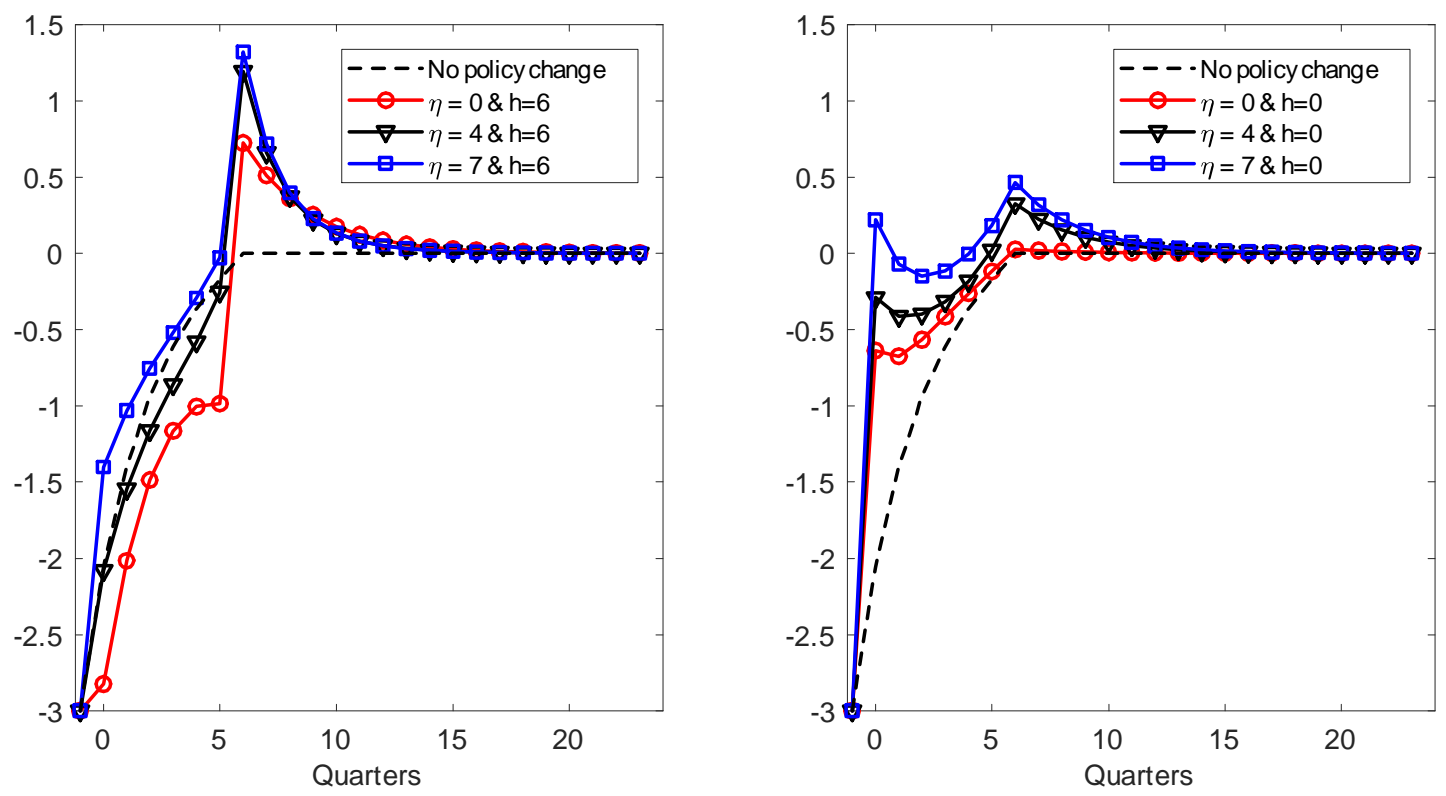

Notes: Output responses are based on the money demand function with the interest semi-elasticity of money demand $(\eta=0,4,7)$. In each panel, the money-financed fiscal stimulus is announced when the economy is in the liquidity trap with $I_{t}=0$. See the notes to Figures $1,3,5$, and 7 for additional details. 
Figure 9: Effects of the interest semi-elasticity of money demand: Liquidity trap
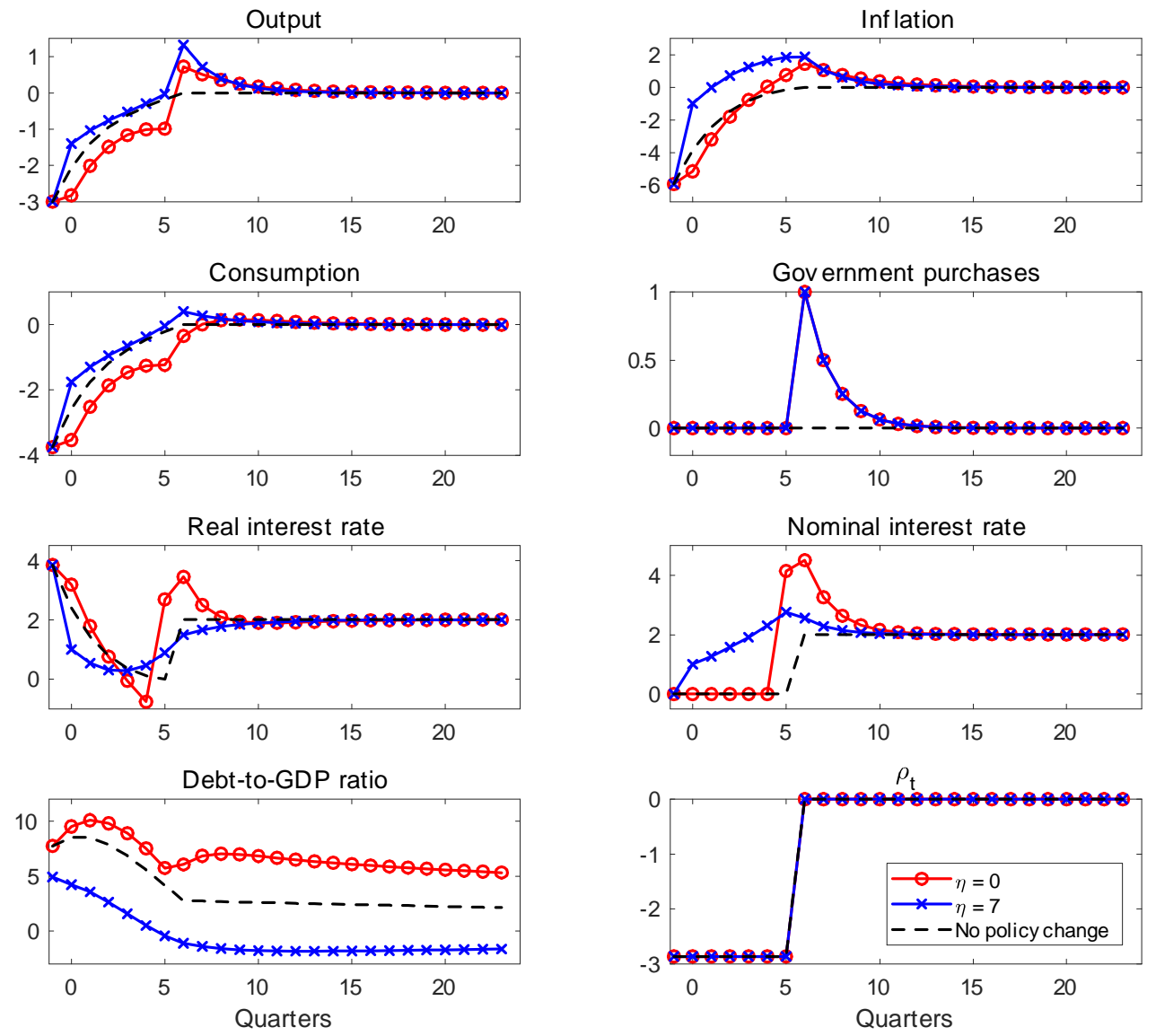

Notes: Responses are based on the money demand function with the interest semi-elasticity of money demand $(\eta=0$ and 7). The solid red line and the solid blue line correspond to the case of $\eta=0$ and $\eta=7$, respectively. In the figure, we assume that $h=6$ and the money-financed fiscal stimulus is announced when the economy is in the liquidity trap with $I_{t}=0$. See the notes to Figures 1,2 and 4 for additional details. 